\title{
INVESTIGASI MINAT DAN MOTIVASI BELAJAR MATEMATIKA SISWA DI ERA COVID-19
}

\author{
Yana $^{1}$, Dewi Purnama Sari ${ }^{2}$ \\ ${ }^{1}$ Program Studi Pendidikan Matematika Sekolah Pascasarjana Universitas \\ Muhammadiyah Prof. DR. HAMKA \\ Email: ydepsya@gmail.com \\ ${ }^{2}$ Program Studi Matematika FMIPA Universitas Pamulang \\ Email: dosen01569@unpam.ac.id
}

\begin{abstract}
This study aims to determine the level of interest and motivation in learning mathematics among students during the Covid-19 pandemic. The distance learning process with more students makes students adapt to be able to study optimally. So it takes interest and motivation to learn mathematics from students during the Covid19 period. This investigation was carried out at Mts Al-Khairiyah Mampang Prapatan South Jakarta in the odd semester of the 2020/2021 school year. The method used is a qualitative case study research with a population of all class VII students, then the sample selection was carried out by purposive sampling technique obtained by class VII-D with a sample size of 30.Data collection techniques were questionnaires of student interest and motivation, interviews and documentation of the learning process. and student work results. The results showed that most of the students had an interest and motivation to learn mathematics at $54.57 \%$. The support of teachers and parents during online learning greatly affects the achievement of the learning process well, some students ask their parents when they experience difficulties in learning. When online learning is inseparable from inhibiting factors, including inadequate mobile phone facilities, especially internet quotas, which have an impact on interest and motivation.
\end{abstract}

Keywords: interest in learning, motivation to learn, the covid-19 pandemic.

\begin{abstract}
ABSTRAK
Penelitian ini bertujuan untuk mengetahui tingkat minat dan motivasi belajar matematika siswa di masa pandemi covid-19. Proses pembelajaran jarak jauh yang dialami siswa membuat siswa harus beradaptasi untuk tetap bisa belajar dengan maksimal. Sehingga dilakukan investigasi minat dan motivasi belajar matematika siswa di masa covid-19. Investigasi ini dilakukan di Mts Al-Khairiyah Mampang Prapatan Jakarta Selatan semester ganjil tahun ajaran 2020/2021. Metode yang dilakukan adalah penelitian kualitatf studi kasus dengan populasi seluruh siswa kelas VII, kemudian pemilihan sampel dilakukan dengan teknik purposive sampling didapat kelas VII-D dengan jumlah sampel 30. Teknik pengumpuan data yaitu dengan angket minat dan motivasi belajar siswa, wawancara serta dokumentasi proses pembelajaran dan hasil pekerjaan siswa. Hasil penelitian menunjukan sebagian besar siswa memiliki minat dan motivasi belajar matematika sebesar $54,57 \%$. Dukungan guru dan orang tua selama belajar online sangat mempengaruhi tercapainya proses belajar dengan baik, sebagian siswa bertanya kepada orang tua saat mengalami kesulitan dalam belajar. Saat pembelajaran online tidak terlepas dari faktor-faktor penghambat diantaranya sarana handphone yang kurang mendukung, kurangnya kuota internet sehingga berdampak kepada minat dan motivasi.
\end{abstract}

Kata kunci : minat belajar, motivasi belajar, pandemi covid-19. 


\section{PENDAHULUAN}

Pemerintah melalui kemendikbud menetapkan cara pembelajaran jarak jauh yaitu melalui daring. Semua pihak diantaranya pemerintah, pihak sekolah, pendidik, siswa serta orang tua harus saling bahu membahu untuk kelancaran proses belajar daring. Melalui pembelajaran, siswa diharapkan menjadi pribadi yang berkualitas baik dalam bidang ilmu pengetahuan, teknologi dan akhlak. Salah satu luaran yang bisa diamati dari proses pembelajaran adalah hasil belajar. Hasil belajar siswa merupakan hal penting dalam kegiatan pendidikan. Ciri hasil belajar bisa dinyatakan dengan skala nilai sebagai prestasi untuk mengukur aspek kognitif (Tambunan, 2018). Untuk itu prestasi dapat diartikan sebagai kemampuan atau penguasaan siswa terhadap suatu materi yang diajarkan.

Mendapatkan hasil belajar yaitu dapat melalui penilaian. Menurut Wilian (2011) hanya melalui penilaian kita bisa menemukan dan mengetahui apakah rangkaian aktivitas pembelajaran tertentu telah menghasilkan yang diinginkan (Van der Kleij et al., 2015). Dengan demikian sebuah penilaian merupakan sarana informasi untuk mengetahui hasil dari proses pembelajaran.

Banyak faktor yang mempengaruhi hasil belajar siswa, salah satunya minat dan motivasi belajar. Banyak penelitian yang sudah dilakukan terkait pengaruh minat dan motivasi terhadap proses pembelajaran. Reynolds \& Walberk mengungkapkan bahwa sikap terhadap matematika dapat memprediksi kinerja akademik dalam matematika dan sains (Singh et al., 2002). Sikap terhadap matematika dapat dibentuk oleh pengaruh sosial, misalnya sikap orang tua maupun guru, dan lebih penting sikap siswa terhadap pelajaran matematika.

Skaalvik \& Rankin (1995) menemukan bahwa motivasi berkaitan erat dengan prestasi akademik (Singh et al., 2002). Proses belajar akan dilakukan dengan baik jika seorang siswa sudah termotivasi baik secara pribadi maupun pengaruh dari luar. Sehingga motivasi belajar menjadi hal yang penting diperhatikan oleh pendidik maupun orang tua. Motivasi dan pembelajaran mungkin memiliki hubungan timbal balik, karena motivasi mempengaruhi siswa dalam menyelesaikan tugas akademiknya.

Sardiman A.M mendefinisikan motivasi yang berkaitan dengan proses belajar yaitu bagian faktor psikis yang bersifat non intelektual yang dapat meningkatkan gairah, rasa senang serta semangat mengikuti proses belajar (Firdaus Daud, 2012). Dengan motivasi tinggi akan memberikan energi kuat untuk belajar maupun mengikuti proses pemebelajaran sehingga akan lebih mudah dalam mencapai prestasi dalam belajar. Motivasi dalam belajar muncul baik dari dalam maupun dari pihak luar, untuk itu motivasi terbagi menjadi dua yaitu motivasi intriksik dan motivasi ekstrinsik. Motivasi dari dalam berkaitan dengan ketertarikan atau kesenangan dalam melakukan sesuatu, sementara motivasi dari luar karena adanya tujuan atau hasil yang ingin dicapai.

Menurut Indaryati (2015) motivasi yaitu salah satu penggerak dalam hati individu untuk mencapai suatu tujuan (Hapsari et al., 2018). Motivasi yang lahir dalam diri individu biasanya berkaitan dengan intelegensi dan bakat. Ini sudah menjadi bawaan setiap individu masing-masing, sehingga untuk meningkatkan motivasi dalam diri bisa dilakukan melalui proses belajar. Dimana proses belajar dapat mempengaruhi motivasi, keinginan, kepuasan, kebiasaan baik dan kesadaran diri. Dari berbagai pendapat para ahli, dapat kita ambil suatu arti dari motivasi belajar yaitu suatu keinginan atau dorongan yang lahir baik dari dalam diri sendiri maupun pengaruh dari luar, untuk melakukan proses pembelajaran dengan baik, sehingga menghasilkan prestasi belajar. 
Bagi banyak psikologi, minat diartikan suatu istilah sehari-hari yang belum jelas menunjukan karakteristik pribadi atau keadaan afektif sehingga perlu dikaji secara menyeluruh oleh psikolog motivasi modern (Schiefele, 1991). Deci \& Ryan (1985) menganggap minat sebagai "keinginan yang mengarahkan perilaku sehingga termotivasi untuk melakukan kegiatan yang menarik bagi seseorang (Schiefele, 1991). Kaitanya dalam proses belajar tentu minat menjadi hal penting harus dimiliki seorang siswa, hal ini dapat mendorong siswa dalam semangat belajar dan mengikuti semua proses pembelajaran.

Minat menurut Slameto (2010) merupakan suatu rasa suka atau ketertarikan (Andriani \& Rasto, 2019). Minat bisa timbul karena adanya interaksi seseorang dengan suatu kegiatan tertentu. Dengan minat dalam diri maka akan memberikan dampak positif khusunya dalam pembelajaran akademik yang menyangkut ilmu pengetahuan. Hidi dan Renninger dalam Wang \& Adesope, tiga aspek dalam pengetahuan yang penting yaitu, perhatian, tujuan dan tingkat pembelajaran (Andriani \& Rasto, 2019). Selain sebagai pendorong dalam belajar, minat juga sebagai faktor penentu sikap. Individu yang memiliki minat khusunya dalam belajar, maka akan terlihat dalam bersikap ketika mempelajari ilmu pengatahuan.

Minat tidak timbul secara tiba-tiba, menurut Bernard minat timbul dari partisipasi, pengalaman, kebiasaan belajar atau bekerja (Sembiring, Rosali, 2013). Terkait minat akan berkaitan dengan kebutuhan maupun keinginan, sehingga pentinya kita menciptakan sebagai guru kondisi yang baik dalam belajar agar siswa selalu tertarik atau butuh belajar terus. Untuk meningkatkan minat belajar yang harus diperhatikan oleh seorang guru yaitu menurut Sanjaya (2008), menyampaikan tujuan pembelajaran sesuai tingkat intelektual siswa, karena pemahaman siswa terhadap tujuan pembelajaran akan menimbulkan minat belajar (Tambunan, 2018). Di sinilah peran guru dalam memulai pembelajaran sangat menentukan proses pembelajaran ke depan.

Winkel (1984) mengatakan bahwa minat merupakan keinginan yang melekat dan tertarik pada suatu bidang atau hal tertentu serta merasa senang ketika berada dalam bidang itu (Murdiyanto \& Mahatama, 2014). Sementara Dimyati dan Mudjiono mengartikan bahwa motivasi adalah dorongan mental untuk menggerakkan maupun mengarahkan sikap dan perilaku seseorang termasuk perilaku dalam belajar (Kamaluddin, 2017). Hal ini dapat kita ambil kesimpulan terkait minat merupakan rasa suka dalam diri individu untuk melakukan suatu kegiatan yang didapat dari hasil interaksi, sehingga menimbulkan semangat untuk melakukan yang terbaik khusunya dalam proses pembelajaran.

Berdasarkan hasil observasi awal ke salah satu guru matematika di MTs Al-Khairiyah Mampang Prapatan menyatakan bahwa selama proses pembelajaran jarak jauh siswa memiliki penurunan hasil belajar matematika pada PTS semester ganjil tahun ajaran 2020/2021. Dugaan awal adalah banyaknya tugas-tugas yang harus dikerjakan siswa hampir setiap hari dan semua mata pelajaran, sementara mereka dalam belajar mandiri memiliki keterbatasan. Hal ini dikuatkan dengan wawancara ke 10 peserta didik pandanganya terhadap pembelajaran online. Belajar matematika perlu banyak latihan dan bimbingan, sementara selama pembelajaran online siswa hanya memperhatikan penjelasan video dan contoh. Bagi siswa yang mempunyai minat dan motivasi belajar tinggi akan berusaha dalam menyelesaikan permasalah, namun bagi siswa yang rendah minat dan motivasi belajarnya hanya akan menunggu jawaban dari teman atau tidak sama sekali mengerjakan. Ketika menemukan kesulitan dalam menyelesaikan, hal pertama yang dilakukan banyak siswa adalah bertanya kepada orang tuanya, namun 
karena keterbatasan pengetahuan orang tua serta kesibukan dalam bekerja sehingga orang tua tidak bisa berbuat banyak dalam membantu menyelesaikan tugas-tugas siswa.

Penelitian terkait minat dan motivasi sudah pernah dilakukan oleh beberapa peneliti, namun dalam kondisi sebelum pandemi covid-19. Diantaranya oleh Ira Novita Sari dan kawan yang menyimpulkan terdapat pengaruh dari minat maupun motivasi dalam belajar terhadap prestasi belajar fisika (Sari et al., 2017). Sementara Arwin Nur Adi dalam penelitianya memperoleh hasil yang menunjukan minat dan motivasi belajar berhubungan terhadap hasil belajar matematika baik secara parsial maupun stimulan (Nur et al., 2019). Berdasarkan latar belekang tersebut, peneliti bermaksud untuk melakukan penelitian terkait minat dan motivasi belajar siswa di masa pandemi Covid19 dengan menganalisis indikator dan faktor yang mempengaruhi.

\section{METODOLOGI}

Penelitian ini menggunakan metode deskriptif kualitatif dengan jenis penelitian studi kasus. Penelitian ini bertujuan untuk medeskripsikan fenomena minat dan motivasi belajar siswa saat pembelajaran online selama pandemi Covid-19 secara mendalam serta menggali faktor-faktor yang mempengaruhi minat dan motivasi belajar siswa dengan teknik triangulasi yaitu observasi, wawancara dan domukentasi kegiatan.

Penelitian ini dilakukan di MTs Al-Khairiyah Mampang Prapatan. Populasi dalam penelitian ini yaitu seluruh siswa kelas VII tahun ajaran 2020/2021 di MTs Al-Khairiyah. Sampel yang digunakan yaitu kelas VII-D kemudian dipilih subjek sebanyak 3 siswa kelas VII-D tahun ajaran 2020/2021. Dalam pemilihan subjek digunakan teknik purposive sampling dengan berdasarkan kriteria kategori minat dan motivasi belajar rendah, sedang serta tinggi.

Tabel 1. Demografi partisipant penelitian

\begin{tabular}{c|c|c|c}
\hline $\begin{array}{c}\text { Minat dan Motivasi } \\
\text { Belajar }\end{array}$ & \multirow{2}{*}{ Jumlah } & \multicolumn{2}{|c}{ Gender } \\
\cline { 3 - 4 } & & $\begin{array}{c}\text { Laki- } \\
\text { laki }\end{array}$ & Perempuan \\
\hline Rendah & 7 & 4 & 3 \\
Sedang & 17 & 10 & 7 \\
Tinggi & 6 & 1 & 5 \\
\hline
\end{tabular}

Tabel tersebut menunjukan kategori minat dan motivasi belajar berdasarkan observasi awal melalui kuesioner minat dan motivasi belajar siswa. Kategori rendah terdiri dari 7 siswa yaitu 4 laki-laki dan 3 perempuan, kategori sedang 17 siswa yang terdiri dari 10 laki-laki dan 7 perempuan sementara kategori tinggi 6 siswa dimana 1 laki-laki dan 5 perempuan.

\subsection{Pengumpulan Data}

Teknik pengumpulan data dalam penelitian ini adalah menggunakan angket untuk mengukur minat dan motivasi belajar siswa melalui google form. Hasil data angket kemudian dikategorikan menurut minat dan motivasi belajar siswa rendah, sedang dan tinggi kemudian 3 siswa sebagai subjek diwawancara online dengan zoom meet untuk menggali lebih dalam (E. Rahmawati et al., 2016) tiap indikator minat dan motivasi belajar siswa tersebut. Validasi intrumen menggunakan validasi ahli yang diadaptasi Rindi Antika (Antika, 2015). 


\subsection{Teknik Analisis Data}

Tahapan analisis data yaitu melalui reduksi, penyajian, penarikan kesimpulan serta verifikasi dan mengecek keabsahan data dengan triangulasi. Teknik triangulasi menurut Sugiyono yaitu teknik dalam mengumpulkan data yang berbeda dari sumber yang sama (Sugiyono, 2013).

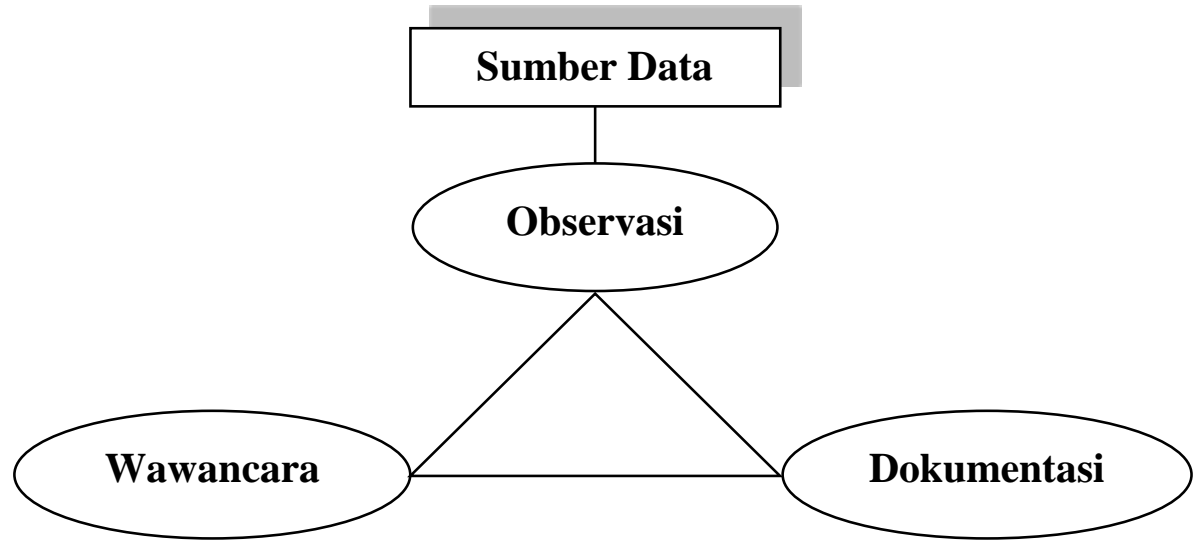

Gambar 1 Teknik Triangulasi

\section{HASIL DAN PEMBAHASAN}

\subsection{Minat dan Motivasi Belajar Matematika Siswa}

Hasil angket minat dan motivasai belajar matematika siswa yang diberikan kepada 30 siswa kelas 7D dapat terlihat tabel 3 di bawah ini:

Tabel 3. Presentase minat dan motivasi belajar siswa

\begin{tabular}{|c|c|c|}
\hline No & Minat \& Motivasi Belajar Matematika & Persentase \\
\hline 1 & $\begin{array}{l}\text { Perasaan senang dan ketertarikan siswa pada pembelajaran } \\
\text { matematika }\end{array}$ & $70,00 \%$ \\
\hline 2 & Perhatian dan keterlibatan siswa dalam pembelajaran. & $63,33 \%$ \\
\hline 3 & $\begin{array}{l}\text { Ulet dan tekun dalam mengerjakan tugas dan menghadapi } \\
\text { kesulitan }\end{array}$ & $53,33 \%$ \\
\hline 4 & Senang mencari dan memecahkan soal-soal & $46,67 \%$ \\
\hline 5 & $\begin{array}{l}\text { Dapat mempertahankan pendapat dan tidak mudah } \\
\text { melepaskan hal yang diyakini }\end{array}$ & $40,00 \%$ \\
\hline & Rata-rata & $54,57 \%$ \\
\hline
\end{tabular}

Berdasarkan tabel di atas dapat terlihat rata-rata persentase minat dan motivasi belajar matematika kelas 7D yaitu 54,57\%. Sehingga sudah sebagian besar memiliki minat dan motivasi belajar matematika meskipun dalam keadaan pandemi Covid-19. Rasa senang maupun ketertarikan terhadap pelajaran matematika pada diri siswa akan menimbulkan dorongan untuk melakukan yang terbaik dalam setiap proses pembelajaran. Minat dan motivasi belajar matematika penting dimiliki oleh siswa sebagai modal untuk mengikuti proses pembelajaran khusunya matematika. Seorang pendidik perlu memahami bagaimana cara meningkatkan minat dan motivasi belajar siswa, karena minat dan 
motivasi bisa ditimbul karena adanya pengaruh rangsangan dari luar terutama pendidik.

\subsection{Hasil Wawancara Minat dan Motivasi Belajar Matematika Siswa}

Untuk mendeskripsikan tiap indikator minat dan motivasi belajar matematika siswa maka dilakukan wawancara kepada 3 siswa sebagai subjek penelitian melalui zoom dengan 5 pertanyaan. Hasil wawancara sebagai berikut:

Jawaban S1 dengan kategori minat tinggi

1. Saya suka pelajaran matematika sejak kecil, karena ada dukungan dari orang tua terutama ibu saya. Ibu saya selalu mengajari matematika dengan cara yang mudah dimengerti saya. Jadi saya suka matematika deh.

2. Saya ingin membanggakan orang tua saya dengan belajar yang rajin. Ketika ada yang belum dimengerti saya nanya orang tua, hehehe

3. Saya termasuk orang yang biasa saja dalam belajar, namun adanya motivasi dan dukungan orang tua jadi tambah semangat. Pengalaman belajar matematika harus diulang-ulang agar paham. Ibu saya selalu memberikan soal kalau saya belum paham.

4. Bertanya kepada orang tua saya dan kadang mencari di internet.

5. Saya orang yang jarang berpendapat, lebih senang untuk mendengarkan pendapat orang lain.

Jawaban S2 kategori minat sedang

1. Pelajaran matematika salah satu pelajaran yang cukup sulit bagi saya namun senang mempelajari.

2. Yang membuat saya fokus adalah cara bapak menjelaskan, dan bertanya di saat saya belum paham.

3. Saya termasuk orang yang sedikit kurang sabar sehingga jika ada yang belum mengerti saya bertanya kepada orang tua saya agar lebih paham.

4. Sumber belajar lainya untuk mengerjakan soal adalah melalui internet.

5. Seingat saya dalam pelajaran matematika jarang terjadi diskusi sehingga saya jarang berpendapat.

Jawaban S3 kategori minat rendah

1. Perasaan dan ketertarikan saya pada pembelajaran matematika stertarik. Karena banyak tantangan hitung.

2. Yang membuat saya fokus adalah soal-soalnya yang rada rumit dan jika belum paham saya akan bertanya kepada guru.

3. Saya bukan termasuk orang yang ulet atau tekun. Pengalaman yaitu sengaja tidak ngerjain PR karena tidak ngerti.

4. Melihat video di youtube atau tanya kepada orang tua

5. Saya jarang mengemukakan pendapat

S1 menyukai belajar matematika, karena latar belakang pendidikan orang tua (Ibu) seorang sarjana matematika. Sehingga dalam belajar matematika merasa termotivasi dan mendapat dukungan cukup baik dari orang tua. Sementara S2 memandang matematika pelajaran yang sulit karena membutuhkan ketelitian dan kesabaran dalam mengerjakan soal-soal. S3 sangat tertarik kepada pelajaran matematika, karena banyak tantangan. Hal 
ini dapat terlihat bahwa perasaan senang dan ketertarikan siswa terhadap pelajaran matematika dapat dipengaruhi oleh faktor internal maupun eksternal. Faktor internal berasal dari diri sendiri seperti cara pandang individu terhadap matematika sehingga mempengaruhi dalam proses pembelajaran. Sementara faktor ekternal bisa timbul dari pengaruh lingkungan diantara orang tua, guru maupun teman.

Perhatian dan keterlibatan siswa selama proses pembelajaran ditunjukan oleh S1, S2 dan S3 dengan baik namun memiliki alasan yang berbeda. S1 karena adanya dorongan dan motivasi orang tua sehingga berusaha maksimal dalam memperhatikan dan terlibat selama proses pembelajaran. Harapan untuk bisa belajar matematika S2 dan S3 berusaha fokus dalam mendengarkan penjelasan guru. Ulet dan tekut dalam belajar ditunjukan oleh S1 karena memandang bahwa belajar matematika perlu diulang-ulang kembali supaya bisa memahami. Ketika menemukan kesulitan bisa mencari sumber lain baik orang tua maupun internet. S1 tergolong anak yang lebih senang mendengarkan pendapat orang lain walau dirinya bisa, ini terlihat ketika ditanya guru dan diperintahkan menjawab soal dapat menjawab dengan baik. Sementara S2 tidak mencoba berusaha terlebih dahulu, sifat yang kurang sabar sehingga langsung bertanya kepada orang tuanya atau mencari penjelasan di internet. Jarang mengemukakan pendapat, namun dalam belajar cukup baik interaksi dengan teman. S2 bukan termasuk yang ulet dan tekun, tapi sebisa mungkin dapat menyelasaikan tugas yang diberikan guru dengan bantuan youtube dan orang tua. Meskipun jarang berpendapat, namun S3 aktif bertanya guru melalui chat WA pribadi untuk materi yang belum dipahami.

\subsection{Keaktifan Siswa Dalam Pembelajaran Matematika}

Dalam proses pembelajaran melalui zoom dari 30 siswa kelas 7D hanya 15 siswa yang mengikuti pembelajaran tersebut. Berbagai kendala sarana diutarakan oleh siswa yang tidak terlibat pembelajaran langsung melalui zoom, diantaranya HP yang tidak mendukung dan kuota internet. Sehingga sebagian siswa pembelajaran melalui group whatsapp. Sehingga guru kurang maksimal dalam menjelaskan materi pembelajaran secara langsung.

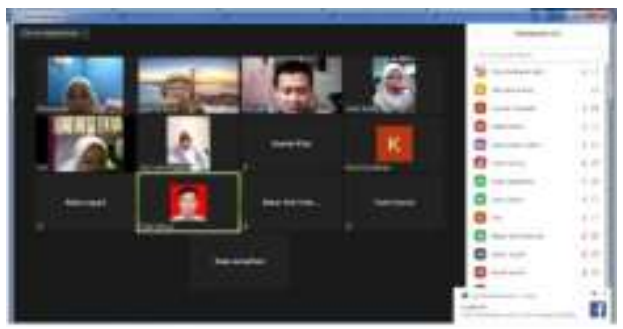

Gambar 2 Kegiatan Pembelajaran
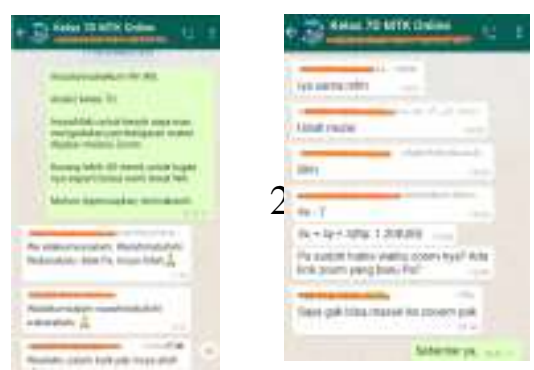


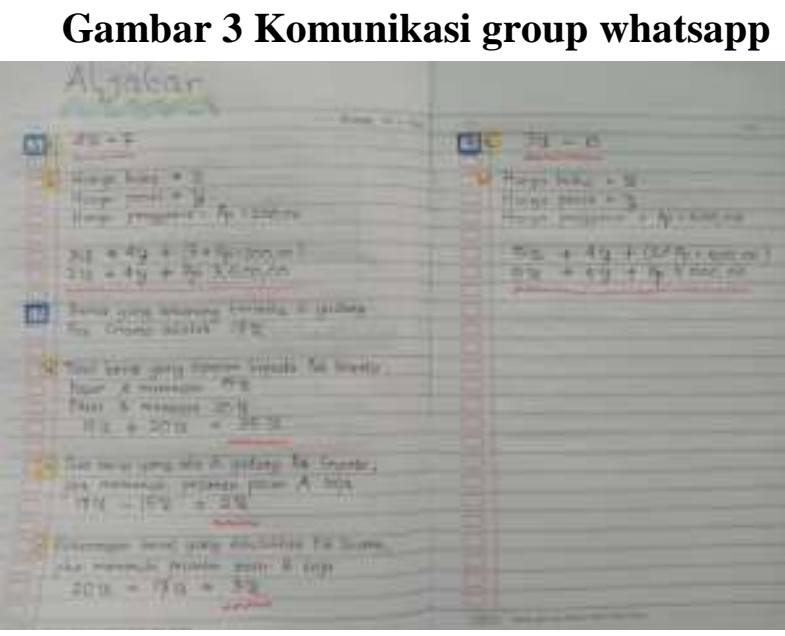

Gambar 4 Hasil Kegiatan Belajar Siswa

Gambar tersebut menunjukan proses pembelajaran melalui zoom meet dan group whatsapp serta hasil salah satu pekerjaan siswa. Minat dan motivasi belajar yang baik akan terlihat dalam kegiatan proses pembelajaran siswa, dari 3 siswa yang di wawancarai menunjukan bahwa mereka berusaha untuk mengikuti dan mengerjakan tugas dalam belajar dengan baik meskipun kondisi belajar secara online.

\subsection{Pembahasan}

Dari hasil penelitian bahwa minat dan motivasi belajar siswa saat pembelajaran online sudah sebagian besar memiliki minat dan motivasi. Namun beberapa siswa mengalami kendala teknis diantaranya fasilitas handphone yang tidak mendukung serta minimnya kuota internet dikarenakan faktor ekonomi orang tua sehingga mempengaruhi minat dan motivasi siswa dalam belajar. Hal ini sejalan dengan penelitian Novi Rosita terkait hambatan dalam belajar daring (N. R. Rahmawati et al., 2020).

Minat dan motivasi belajar yang baik akan terlihat dalam kegiatan proses pembelajaran siswa, dari 3 siswa yang di wawancarai menunjukan bahwa mereka berusaha untuk mengikuti dan mengerjakan tugas dalam belajar dengan baik meskipun kondisi belajar secara online. Sejalan dengan hasil penelitian K. Singh bahwa minat, motivasi dan hasil akademik memiliki keterikatan satu sama lain (Singh et al., 2002), kemudian dikuatkan kembali oleh seorang psikolog bahwa minat dan motivasi siswa penting untuk diketahui seorang pendidik dengan harapan mampu dalam membangkitkan minat dan motivasi belajar siswa (Schiefele, 1991). Adanya minat dan motivasi yang kuat pada diri siswa sehingga menimbulkan dampak positif dalam mengikuti setiap proses pembelajaran terlebih saat ini pembelajaran secara online.

\section{SIMPULAN}

Berdasarkan hasil analisis minat, motivasi, wawancara, serta keaktifan siswa 
selama pembelajaran online terlihat bahwa sebagian besar siswa memiliki minat dan motivasi dalam belajar. Dukungan guru dan orang tua sangat penting dalam pembelajaran online, sebagian siswa dengan minat dan motivasi kurang dikarenakan memandang matematika adalah pelajaran yang sulit sehingga mindset itu tertanam dalam pikiranya yang berdampak kepada minat dan motivasi dalam belajar. Selain itu saat siswa menghadapi kesulitan dalam memahami materi matematika secara mandiri tidak memiliki banyak tempat untuk bertanya, kesibukan orang tua dalam bekerja sehingga kurangnya kepedulian terhadap tugas-tugas siswa di rumah. Selain itu faktor ekonomi berdampak terhadap keberlangsungan proses pembelajaran online, kurangnya kuota internet membuat siswa tidak bisa mengikuti pembelajaran secara langsung sehingga memperoleh penjelasan kurang maksimal.

Berdasarkan kesimpulan penelitian tersebut, maka menjadi menarik untuk dilakukan penelitian lanjutan tentang cara meningkatkan minat dan motivasi belajar siswa di masa pandemi Covid-19 dengan menggunakan berbagai pendekatan dan media pembelajaran interaktif.

\section{DAFTAR PUSTAKA}

Andriani, R., \& Rasto, R. (2019). Motivasi belajar sebagai determinan hasil belajar siswa. $\begin{array}{llll}\text { Jurnal Pendidikan Manajemen Perkantoran, } & 4(1), \quad 80 .\end{array}$ https://doi.org/10.17509/jpm.v4i1.14958

Antika, R. (2015). Pembelajaran Matematika Kontekstual untuk Meningkatkan Literasi Matematis dan Motivasi Belajar Siswa SMP Universitas Pendidikan Indonesia | repository.upi.edu | perpustakaan.upi.edu.

Firdaus Daud. (2012). Pengaruh Kecerdasan Emosional (EQ) Dan Motivasi Belajar Terhadap Hasil Belajar Biologi Siswa SMA 3 Negeri Kota Palopo. Jurnal Pendidikan Dan Pembelajaran Universitas Negeri Malang, 19(2), 243-255. http://journal.um.ac.id/index.php/pendidikan-dan-pembelajaran/article/view/3475/626

Hapsari, D. I., Airlanda, G. S., Profesi, P., Universitas, G., \& Satya, K. (2018). Penerapan Project Based Learning Untuk Meningkatkan Motivasi Belajar Matematika Peserta Didik Kelas V Implementation of Project Based Learnng To Improve Mathematics Learning Motivation the. 5(2), 154-161.

Kamaluddin, M. (2017). Pengaruh Motivasi Belajar Terhadap Prestasi Belajar Matematika dan Strategi untuk Meningkatkannya. Seminar Matematika Dan Pendidikan Matematika, 455-460.

Murdiyanto, T., \& Mahatama, Y. (2014). Pengembangan Alat Peraga Matematika Untuk Meningkatkan Minat Dan Motivasi Belajar Matematika Siswa Sekolah Dasar. Sarwahita, 11(1), 38. https://doi.org/10.21009/sarwahita.111.07

Nur, A., Prasetyo, A. D. I., Studi, P., Matematika, P., Keguruan, F., Ilmu, D. A. N., \& Surakarta, U. M. (2019). Hubungan Minat dan Motivasi Belajar Siswa Terhadap Hhasil Belajar Matematika Kelas VII di MTs N 2 Surakarta. 
Rahmawati, E., Annajmi, \& Hardianto. (2016). Analisis Kemampuan Matematis Siswa SMP dalam Menyelesaikan Soal Matematika Bertipe PISA. Jurnal Ilmiah Mahasiswa Matematika, 2(2), 1-5.

Rahmawati, N. R., Rosida, F. E., \& Kholidin, F. I. (2020). Analisis Pembelajaran Daring Saat Pandemi Di Madrasah Ibtidaiyah. SITTAH: Journal of Primary Education, 1(2), 139-148. https://doi.org/10.30762/sittah.v1i2.2487

Sari, I. N., Saputri, D. F., \& Sasmita, S. (2017). Pengaruh Minat Dan Motivasi Belajar Terhadap Prestasi Belajar Fisika Pada Siswa Kelas XI IPA SMA Negeri 1 Galing Kabupaten Sambas. Jurnal Edukasi Matematika Dan Sains, 4(2), 108. https://doi.org/10.25273/jems.v4i2.691

Schiefele, U. (1991). Interest, Learning, and Motivation. Educational Psychologist, 26(3-4), 299-323. https://doi.org/10.1080/00461520.1991.9653136

Sembiring, Rosali, M. (2013). Strategi Pembelajaran Dan Minat Belajar Terhadap Hasil Belajar Matematika. Jurnal Teknologi Pendidikan (JTP), 6(2), 34-44. https://doi.org/10.24114/jtp.v6i2.4996

Singh, K., Granville, M., \& Dika, S. (2002). Mathematics and science achievement: Effects of motivation, interest, and academic engagement. Journal of Educational Research, 95(6), 323-332. https://doi.org/10.1080/00220670209596607

Sugiyono. (2013). Metode Penelitian Kualitatif dan R\&D. Alfabeta.

Tambunan, H. (2018). The Dominant Factor of Teacher's Role as A Motivator of Students' Interest and Motivation in Mathematics Achievement. International Education Studies, 11(4), 144. https://doi.org/10.5539/ies.v11n4p144

Van der Kleij, F. M., Feskens, R. C. W., \& Eggen, T. J. H. M. (2015). Effects of Feedback in a Computer-Based Learning Environment on Students' Learning Outcomes: A MetaAnalysis. Review of Educational Research, 85(4), 475-511. https://doi.org/10.3102/0034654314564881 